\title{
British and American Literature Teaching and Humanistic Thought Penetration
}

\author{
XU Li-mei, ZHANG Quan-feng \\ Changchun University, Changchun, China
}

\begin{abstract}
Improving students' appreciation of literature and analysis of the force are always a focus in British and American literature teaching. British and American literature teachers consciously cultivate students' emotion of English and American literature in the process of teaching activities will contribute to students' literary accomplishment. In learning English and American literature, humanism is an indispensable learning content. And will be helpful to improve students' language skills when teachers permeate the ideas of humanistic thought in the teaching activities in class. Students can promote their perfection of personality through the influence of humanistic thought. In this paper, the author carry on a simple analysis of the British and American literature teaching and the penetration of humanistic thought, in order to learn more about concrete and effective British and American literature teaching ways of promoting students' better learning.
\end{abstract}

Keywords: literature teaching, humanistic thought, penetration

\section{Introduction}

The open of British and American literature course produces certain positive effect on the promotion of students' language skills. Students can promote their perfection of personality through the influence of humanistic thought. And the purpose of the English and American literature courses is also in shaping the students' personality. The essence of the British and American literature teaching will be affected by the British and American literature itself. While students will be affected by this course in the process of learning literary works, which plays an important role in the formation of humanistic spirit. Therefore, using the English and American literature teaching not only can shape students' personality, but also help improve students' language skills in the process of the implementation of teaching activities.

\section{The Present Situation of the British and American Literature Teaching}

Today, British and American literature course has built up for a period of time; the students already have related knowledge through learning this course, and their own language and personality have a significant improvement. However, it still exists some shortcomings from the perspective of the status quo of British and American literature teaching. The author believes that the deficiency of British and American literature teaching

XU Li-mei, lecturer, master, Foreign Languages College, Changchun University.

ZHANG Quan-feng, lecturer, master, Foreign Languages College, Changchun University. 
is mainly manifested in the following respects.

\section{Course Setting of British and American Literature is Not Scientific}

The British and American literature course setting lacks certain scientific nature from its actual situation. As is known to all, English and American literature teaching can help to train students' formation of correct values based on the students' basic skill increases. British and American literature teaching will direct impact on students both of the two aspects. Nowadays, the teaching of the course reform is in full swing, due to the influence of the curriculum reform, the curriculum of English and American literature teaching generally presents the current situation of English teaching from the perspective of the status quo of British and American literature teaching. Teachers ignore the humanities teaching content in the process of teaching activities, and focus teaching emphasis on students' English learning. What can be seen from the present situation of British and American literature teaching is that teachers ignore the comprehensive development of students in teaching. Nowadays, cultivating the students' comprehensive quality will be helpful to improve students' ability to adapt to the rapid development of society. In fact, the cultivation of the students' comprehensive quality is really emotional education a little bit of accumulated in the process of learning. From the point of college English and American literature curriculum, students' time used to contact relatively less. Even if the college has opened English and American literature courses, the course does not cause the attention of teachers. Learning atmosphere is not active in the process of British and American literature teaching, which results in raw negative influence on the English and American literature learning to a certain extent.

\section{Teaching Methods of British and American Literature Are Laggard}

British and American literature course is usually opened in the junior year from the condition of various universities. University is a special period for teenagers; because of a variety of reasons, junior and senior students can not keep the rhythm of the same class not with freshman and sophomore students. Students coming to class will focus on the teacher's classroom activities. However, British and American literature teachers make themselves as the center in the process of implementation of teaching activity. In accordance with the traditional teaching ideas on teaching, this traditional teaching mode always makes the students in a passive position. Besides, students mainly understand and memorize knowledge through the notes in class. Therefore, British and American literature teaching methods behind students' enthusiasm and initiative in British and American literature study to a certain degree. It is difficult for students to express out their true feelings, and they also have difficulty in the process of understanding the connotation of the works when appreciating literary works. British and American literature course will lost its original vitality if teachers adopt the traditional way in a long term, which is hard to play the role of cultivating students' personality and language skills in teaching quality.

\section{The Possibility of the Humanistic Thought Penetration in British and American Literature Teaching}

As is known to all, literature can play the role of education in the teaching. Readers will understand the nature of things through the literature meaning, and then understand the real creation intention authors hidden in the text. Of course, different people have different understanding of literature function. Usually, a good literary 
works can play the role of cheering the reader in the eyes of readers. When appreciating literary works, the value of a literary text lies in the deeper meaning, value and closely linked of the article. As a result, the teacher will be helpful for students to deeper understand the literary works through explaining and complement to the students' humanistic value in British and American literature teaching. Teachers should fully highlight the effect of education with pleasure in the process of English and American literature teaching, and show the two functions of literary works in teaching activities. The nature of the British and American literature teaching remains educational from the point of the current teaching situation. As a result, on the one hand, teachers should pay attention to the detail analysis of level of fine art and literature in the process of British and American literature teaching activities to explain the role of literature. On the other hand, the teacher should dig the different degree of ideological education according to different, types of literary works in the process of teaching. In fact, it can be seen from the present situation of British and American literature teaching that teachers make students experience the spot the richness of the world through their interpretation of the literary works, which will encourage the student to obtain perceptual knowledge of the world when they revel in the work. Thus, there is possibility for teachers to penetrate humanistic thought in English and American literature teaching.

\section{Measures of the Penetration of Humanistic Thought in British and American Literature Teaching}

From the previous research, people can see that the infiltration of humanistic thinking plays an important role in the British and American literature teaching. Humanistic ideas have an important effect on the cultivation of the students' ability in all aspects. Therefore, people should strengthen the infiltration of humanistic thought in British and American literature teaching.

\section{Strengthen the Combination of Humanistic Thought and the Teaching Goal in Teaching}

There will not too much limit to the classroom content in the process of British and American literature teaching activities. To ensure the smooth of the teaching activities carried out, the teacher should determine the teaching objective at the beginning of the teaching. With the teaching goal, teachers can make clear the teaching content according to the teaching goal. Therefore, teachers should combine the teaching content with humanistic ideas together in teaching process, set up corresponding teaching task, and create some of the practical significance teaching goal for the students. Students will realize the value of the British and American literature and shape their personality with the completion of the teaching goal. This kind of teaching method helps students to establish correct outlook on life, and then form their own values. Thus, the combination of humanistic ideas and teaching goal made by English and American literature teaching has positive significance for students' turning their own personality.

\section{Innovative Teaching Methods}

As is known to all, English and American literature teaching content is very wide; the literary works showed in classroom are from all over the world. These literary works generally has certain representativeness, at the same time, they are the crystallizations of the wisdom of author. The literary works learned in the teaching activities generally has the rich cultural background and connotation, which is a microcosm of society at that time. Therefore, teachers should organize students appreciate the literary works in the process of teaching activities, be 
fully aware of the learning subjectivity of students, and make the students actively involved in the appreciation of literary works. Thus, students will form their own opinions through the appreciation of literary works. At the same time, teachers should also encourage students to bold in this link to their comments, and explain their understanding of literary works with other students or teachers, which will do great help to improve their appreciation ability of British and American literature. At the same time, this way will have a positive effect on students to master language skills. In addition, teachers should pay attention to the interpretation of humanism in content teaching, in order to let the students fully understand the charm of humanistic thought of British and American literature teaching. For example, when teaching Young Goddm Brown, teachers can try to explain the novel from the aspect of art. Thus, teachers elaborate the social background at that time, make the students to have a relatively clear understanding of the American society with the help of the novel. After the artistic interpretation of the novel, the teacher can communicate with students to discuss the reason of human goodness. Thus, in the process of interpretation of the teachers, teachers of English and American literature carry out by using different methods of interpretation of the education, and different teaching effect can be obtained.

\section{Train Students' Correct Values}

British and American literature teaching styles come from the literary works from all countries. Literary works includes a variety of different values and outlook on life. Teachers should pay attention to train students' correct values in the process of teaching activities. The relevant information in the literature will produce certain effect on the students, so teachers should learn to guide students in teaching process, and help them cultivate correct values in the process learning. The stories of literary works are from life. People and events are likely to happen in life in the literary works. Teachers can play a good guidance effect on the student through the guidance and education to the students in the classroom, and accelerate the development of students. For example, in Jane eyre work, teachers can make the students have a more intuitive understanding of the hero' personality scharm with the explanation of their character and spirit, and constantly shape the students own personality and improve themselves.

\section{Conclusion}

How to permeate humanistic connotation in British and American literature teaching has become an important core concept teaching. British and American literature teaching in college teaching course is a basic course; only when the teaching of the humanities thought penetration work is done can we realize the value of the British and American literature teaching.

\section{References}

Benson, P. (2001). Teaching and researching autonomy in language learning. Cambridge: Pearson Education Limited.

Benson, P., \& Voller, P. (1997). Autonomy and ideendence in language learning. London: Longman.

FAN, X. H. (2010). British and American literature teaching and the shaping of harmonious personality of college students. Chinese School Education (Theory), 20-22.

HU, M. (2009). Research on British and American literature teaching and college students' thinking ability training. Journal of Hunan tide (Second Half) (Theory), 23-24.

HUI, J. R. (2010). Problems and solving methods in British and American literature in the undergraduate course teaching. Journal of Qiqihar Medical College, 25-26.

Stern, H. H. (1997). Fundamental concepts of language teaching (pp. 48-50). Shanghai: Shanghai Foreign Education. 
TAN, Z. Y. (2010). Successful quality education idea in the fine course construction of comprehensive English. Journal of Hubei Radio and TV University, 89.

WANG, L. Y., \& NIU, J. W. (2013). Pay attention to the British and American literature teaching, improve students' comprehensive quality. Journal of Jiamusi University Journal of Social Science, 26. 